\title{
Construction of the influenza A virus infection- induced cell-specific inflammatory regulatory network based on mutual information and optimization
}

\author{
Suoqin Jin and Xiufen Zou
}

\begin{abstract}
Background: Influenza A virus (IAV) infection-induced inflammatory regulatory networks (IRNs) are extremely complex and dynamic. Specific biological experiments for investigating the interactions between individual inflammatory factors cannot provide a detailed and insightful multidimensional view of IRNs. Recently, data from high-throughput technologies have permitted system-level analyses. The construction of large and cell-specific IRNs from high-throughput data is essential to understanding the pathogenesis of IAV infection.

Results: In this study, we proposed a computational method, which combines nonlinear ordinary differential equation (ODE)-based optimization with mutual information, to construct a cell-specific optimized IRN during IAV infection by integrating gene expression data with a prior knowledge of network topology. Moreover, we used the average relative error and sensitivity analysis to evaluate the effectiveness of our proposed approach. Furthermore, from the optimized IRN, we confirmed 45 interactions between proteins in biological experiments and identified 37 new regulatory interactions and 8 false positive interactions, including the following interactions: IL $1 \beta$ regulates TLR3, TLR3 regulates IFN- $\beta$ and TNF regulates IL6. Most of these regulatory interactions are statistically significant by Z-statistic. The functional annotations of the optimized IRN demonstrated clearly that the defense response, immune response, response to wounding and regulation of cytokine production are the pivotal processes of IAV-induced inflammatory response. The pathway analysis results from the Kyoto Encyclopaedia of Genes and Genomes (KEGG) showed that 8 pathways are enriched significantly. The 5 pathways were validated by experiments, and 3 other pathways, including the intestinal immune network for IgA production, the cytosolic DNA-sensing pathway and the allograft rejection pathway, are the predicted novel pathways involved in the inflammatory response.

Conclusions: Integration of knowledge-driven and data-driven methods allows us to construct an effective IRN during IAV infection. Based on the constructed network, we have identified new interactions among inflammatory factors and biological pathways. These findings provide new insight into our understanding of the molecular mechanisms in the inflammatory network in response to IAV infection. Further characterization and experimental validation of the interaction mechanisms identified from this study may lead to a novel therapeutic strategy for the control of infections and inflammatory responses.
\end{abstract}

\footnotetext{
* Correspondence: xfzou@whu.edu.cn

School of Mathematics and Statistics, Wuhan University, Wuhan 430072

China
} 


\section{Background}

Influenza A virus (IAV) infection is a worldwide public health threat [1,2]. IAV causes respiratory tract infections and leads to inflammatory responses. Controlling the inflammatory response resulting from an IAV infection is of great significance in reducing associated tissue damage. However, many biological experiments have demonstrated that IAV infection-induced inflammatory responses are extremely complicated and regulated by dynamic networks [3-5]. Specific biological experiments investigating the mechanisms of interactions among individual inflammatory factors have not provided a sufficiently detailed and insightful multidimensional view of inflammatory regulatory networks (IRNs). We need to investigate the mechanisms at a system-level and from the network dynamics. Therefore, the construction of large and cell-specific inflammatory regulatory networks (IRNs) based on high-throughput data is essential for investigating the molecular mechanisms of inflammatory responses during IAV infection.

Biological experiments have found that IAVs induce the expression of a number of inflammatory molecules and inflammatory cytokines and chemokines, such as IL27, IL32, IL6, TNF, IFNG, CXCL10, CCL3, NOS2 and IL8 [6-9]. Furthermore, a number of studies have shown that the H5N1 viruses can induce increased gene transcription of pro-inflammatory cytokines, including CXCL10, IFN- $\beta$, IL6, COX-2 (Cyclooxygenase-2) and CCL5 [9-12]. In particular, COX-2 is the primary mediator in protection against IAV infection [4] and has been shown to play a regulatory role in the induction of the H5N1-mediated pro-inflammatory cascade $[10,11]$. It is important to further investigate the mechanisms of the inflammatory cascade downstream of COX-2 regulation that may be involved in H5N1 infection [13]. To our best knowledge, the studies on constructing a cell-specific IRN after IAV infection are limited, and an integrated and systematic analysis of the inflammatory cascade mediated by COX-2 that incorporates microarray data has not yet been reported.

A number of different methods for inferring gene regulatory networks (GRNs) from high-throughput data have been proposed [14-20]. However, there are a few studies on the construction of dynamic signaling networks based on stoichiometric approaches, discrete Boolean models, the fuzzy logic models, the integer programming method and the ordinary differential equation (ODE)-based method [15,21-27]. No study has reported combining a prior knowledge of network topology with nonlinear optimization algorithms to identify the dynamic regulatory network. In the process of reconstructing networks from expression data based on a priori knowledge of network topology, the most important steps are converting familiar network maps into mathematical models and fitting the available data into the network's structural parameters. Recently, the rough topological structure of inflammatory networks with 2361 nodes and 63276 edges in humans have been obtained, which provides a prelude to more detailed network analysis and mathematical modeling for an inflammatory network [28]. By combining information theory-based MI and nonlinear ODE-based optimization, in this study, we proposed a computational method to construct a cellspecific IRN mediated by COX-2 during IAV infection. A differential evolution (DE) algorithm was used to optimize the network so that it best fits the experimental data. Furthermore, we performed a Kyoto Encyclopaedia of Genes and Genomes (KEGG) pathway and gene ontology (GO) terms enrichment analysis on the optimized IRN to identify the underlying mechanisms during IAV infection.

\section{Methods}

The flowchart of our work is presented in Figure 1 and mainly consists of six steps: constructing an initial IRN, simplifying the initial network, building a mathematical model, estimating parameters in the model with the DE algorithm, significance test and sensitivity analysis for the regulations, and performing an enrichment analysis.

\section{Data collection and construction of the initial inflammatory regulatory network}

To construct a cell-specific IRN and investigate the mechanisms of the inflammatory cascade mediated by COX-2 in IAV infection, we selected 59 proteins, which are listed in Table 1, that are associated with the inflammatory responses regulated by COX-2 based on the published literature $[3,9,13,29,30]$. The microarray data were retrieved from the Gene Expression Omnibus (GEO) database under the GEO accession number GSE28166 [31,32]. This dataset contains 36 samples in total, with 3 mock and infected replicates for each time point. In this study, the expression levels of complexes were the average of the gene expression levels of the members of the complex from the dataset. The expression level of IAV was obtained from the literature [32].

Network construction based on these 59 proteins was performed using Ingenuity Pathway Analysis (IPA) software (Ingenuity Systems, www.ingenuity.com ). The official symbol of each protein was imported into the IPA software. Through IPA analysis, we identified a total of 7 networks based on functional connectivity. Three of these networks shared common proteins, and it was possible to generate a merged network (data not shown). The merged network is very complicated and includes a few proteins that are not on our protein list. We pruned the network by removing the proteins that were not on 




our list except for some common and important molecules, such as NFkB, IL12 (complex), p38 MAPK, JAK, STAT, IFN- $\alpha$ and IFN- $\beta$. In addition, we integrated two molecules, IAV and COX-2, into the merged network. IL32, IL29, IL27, IL1 $\beta$ and IFN- $\alpha / \beta / \gamma$ have been reported to inhibit viral replication [3,33-37]. Therefore, we obtained our initial IRN comprising 51 proteins (or complexes) and 198 interactions. The network is depicted in Additional file 1. The full name of each protein in the initial IRN is listed in Additional file 2.

\section{Simplifying the initial IRN based on conditional mutual information}

PCA-CMI, which was originally proposed by Zhang et al. for inferring GRNs from gene expression data, considers the nonlinear dependence and topological structure of GRNs by employing a path consistency algorithm (PCA) based on conditional mutual information (CMI) [20]. In this study, we used the PCACMI method to distinguish direct (or causal) interactions from indirect associations.

For a discrete variable $X$, the entropy $H(X)$ is the measure of average uncertainty of variable $X$ and can be defined by:

$$
H(X)=-\sum_{x \in X} p(x) \log p(x),
$$

where $p(x)$ is the probability of each discrete value $x$ in $X$.

Mutual information (MI) measures the dependency between two variables (genes or proteins). For discrete variables $X$ and $Y, \mathrm{MI}$ is defined by the following equation:

$$
I(X, Y)=-\sum_{x \in X, y \in Y} p(x, y) \log \frac{p(x, y)}{p(x) p(y)} .
$$

CMI measures conditional dependency between two variables given other variable(s). The CMI of variables $X$ and $Y$ given $Z$ is defined as:

$$
I(X, Y \mid Z)=-\sum_{x \in X, y \in Y, z \in Z} p(x, y, z) \log \frac{p(x, y \mid z)}{p(x \mid z) p(y \mid z)} .
$$

With the widely adopted Gaussian kernel probability density estimator, the equations (1), (2) and (3) can be easily calculated using the following equivalent equations $[15,20]$.

$$
\begin{aligned}
& H(X)=\frac{1}{2} \log (2 \pi e)^{n}|C|, \\
& I(X, Y)=\frac{1}{2} \log \frac{|C(X)| \cdot|C(Y)|}{|C(X, Y)|}, \\
& I(X, Y \mid Z)=\frac{1}{2} \log \frac{|C(X, Z)| \cdot|C(Y, Z)|}{|C(Z)| \cdot|C(X, Y, Z)|}
\end{aligned}
$$

where $C$ is the covariance matrix of variable $X,|C|$ is the determinant of matrix $C$, and $n$ is the number of variables in $C$.

A high MI value indicates that there is a close relationship between the variables, while a low MI value implies variable independence. Similarly, a high CMI 
Table 1 Total 59 proteins selected from the published literatures

\begin{tabular}{|c|c|c|}
\hline $\begin{array}{l}\text { Gene } \\
\text { symbol }\end{array}$ & Description & Type \\
\hline BPIFA1 & BPI fold containing family A, member 1 & Other \\
\hline CCL16 & Chemokine ligand 16 & Cytokine \\
\hline CCL2 & Chemokine (C-C motif) ligand 2 & Cytokine \\
\hline CCL22 & Chemokine (C-C motif) ligand 22 & Cytokine \\
\hline CCL5 & Chemokine (C-C motif) ligand 5 & Cytokine \\
\hline CCR9 & Chemokine (C-C motif) receptor 9 & $\begin{array}{l}\text { G-protein } \\
\text { coupled receptor }\end{array}$ \\
\hline CD14 & CD14 molecule & $\begin{array}{l}\text { Transmembrane } \\
\text { receptor }\end{array}$ \\
\hline CD27 & CD27 molecule & $\begin{array}{l}\text { Transmembrane } \\
\text { receptor }\end{array}$ \\
\hline CMKLR1 & Chemokine-like receptor 1 & $\begin{array}{l}\text { G-protein } \\
\text { coupled receptor }\end{array}$ \\
\hline CSF2RA & $\begin{array}{l}\text { Colony stimulating factor } 2 \text { receptor, } \\
\text { alpha }\end{array}$ & $\begin{array}{l}\text { Transmembrane } \\
\text { receptor }\end{array}$ \\
\hline CXCL10 & Chemokine(C-X-C motif) ligand 10 & Cytokine \\
\hline CXCL12 & Chemokine(C-X-C motif) ligand 12 & Cytokine \\
\hline CXCR3 & Chemokine(C-X-C motif)receptor 3 & $\begin{array}{l}\text { G-protein } \\
\text { coupled receptor }\end{array}$ \\
\hline CXCR4 & Chemokine(C-X-C motif)receptor 4 & $\begin{array}{l}\text { G-protein } \\
\text { coupled receptor }\end{array}$ \\
\hline CXCR5 & Chemokine(C-X-C motif)receptor 5 & $\begin{array}{l}\text { G-protein } \\
\text { coupled receptor }\end{array}$ \\
\hline ERBB2 & $\begin{array}{l}\text { V-erb-b2 erythroblastic leukemia viral } \\
\text { oncogene homolog } 2\end{array}$ & Kinase \\
\hline FADD & $\begin{array}{l}\text { Fas (TNFRSF6)-associated via death } \\
\text { domain }\end{array}$ & Other \\
\hline FGF23 & Fibroblast growth factor 23 & Growth factor \\
\hline FGFRL1 & Fibroblast growth factor receptor-like 1 & $\begin{array}{l}\text { Transmembrane } \\
\text { receptor }\end{array}$ \\
\hline HGF & $\begin{array}{l}\text { Hepatocyte growth factor (hepapoietin A; } \\
\text { scatter factor) }\end{array}$ & Growth factor \\
\hline HRG & Histidine-rich glycoprotein & Other \\
\hline IFNB1 & Interferon, beta 1, fibroblast & Cytokine \\
\hline IFNG & Interferon, gamma & Cytokine \\
\hline IL12B & Interleukin 12B & Cytokine \\
\hline IL15RA & Interleukin 15 receptor, alpha & $\begin{array}{l}\text { Transmembrane } \\
\text { receptor }\end{array}$ \\
\hline IL16 & Interleukin 16 & Cytokine \\
\hline IL18BP & Interleukin 18 binding protein & Other \\
\hline IL1 $\beta$ & Interleukin 1, beta & Cytokine \\
\hline IL20RA & Interleukin 20 receptor, alpha & $\begin{array}{l}\text { Transmembrane } \\
\text { receptor }\end{array}$ \\
\hline IL22RA2 & Interleukin 22 receptor, alpha 2 & $\begin{array}{l}\text { Transmembrane } \\
\text { receptor }\end{array}$ \\
\hline IL25 & Interleukin 25 & Cytokine \\
\hline IL27 & Interleukin 27 & Cytokine \\
\hline IL29 & Interleukin29(interferon, lambda 1) & Other \\
\hline
\end{tabular}

Table 1 Total 59 proteins selected from the published literatures (Continued)

\begin{tabular}{|c|c|c|}
\hline IL2RA & Interleukin 2 receptor, alpha & $\begin{array}{l}\text { Transmembrane } \\
\text { receptor }\end{array}$ \\
\hline IL32 & Interleukin 32 & Other \\
\hline IL6 & Interleukin 6 (interferon, beta 2) & Cytokine \\
\hline IL6R & Interleukin 6 receptor & $\begin{array}{l}\text { Transmembrane } \\
\text { receptor }\end{array}$ \\
\hline IL7 & Interleukin 7 & Cytokine \\
\hline $\mathrm{KIT}$ & $\begin{array}{l}\text { V-kit Hardy-Zuckerman } 4 \text { feline sarcoma } \\
\text { viral oncogene homolog }\end{array}$ & Kinase \\
\hline LTA & $\begin{array}{l}\text { Lymphotoxin alpha (TNF superfamily, } \\
\text { member 1) }\end{array}$ & Cytokine \\
\hline LTBP1 & $\begin{array}{l}\text { Latent transforming growth factor beta } \\
\text { binding protein } 1\end{array}$ & Other \\
\hline MET & Met proto-oncogene & Kinase \\
\hline MMP19 & Matrix metallopeptidase 19 & Peptidase \\
\hline NGF & Nerve growth factor & Growth factor \\
\hline NOS2 & Nitric oxide synthase 2 , inducible & Enzyme \\
\hline NRG2 & Neuregulin 2 & Growth factor \\
\hline PECAM1 & $\begin{array}{l}\text { Platelet/endothelial cell adhesion } \\
\text { molecule }\end{array}$ & Other \\
\hline SAA1 & Serum amyloid A1 & Transporter \\
\hline SELL & Selectin L & Other \\
\hline SMAD9 & SMAD family member 9 & $\begin{array}{l}\text { Transcription } \\
\text { regulator }\end{array}$ \\
\hline TGFB1 & Transforming growth factor, beta 1 & Growth factor \\
\hline TIMP4 & TIMP metallopeptidase inhibitor 4 & Other \\
\hline TLR3 & Toll-like receptor 3 & $\begin{array}{l}\text { Transmembrane } \\
\text { receptor }\end{array}$ \\
\hline TMEFF2 & $\begin{array}{l}\text { Transmembrane with EGF-like and two } \\
\text { follistatin-like domains } 2\end{array}$ & Other \\
\hline TNF & Tumor necrosis factor & Cytokine \\
\hline TNFSF10 & $\begin{array}{l}\text { Tumor necrosis factor (ligand) superfamily, } \\
\text { member } 10\end{array}$ & Cytokine \\
\hline TNFSF12 & $\begin{array}{l}\text { Tumor necrosis factor (ligand) superfamily, } \\
\text { member } 12\end{array}$ & Cytokine \\
\hline TNFSF14 & $\begin{array}{l}\text { Tumor necrosis factor (ligand) superfamily, } \\
\text { member } 14\end{array}$ & Cytokine \\
\hline
\end{tabular}

The gene symbol, description and type corresponding to each protein are given.

indicates that there is a close relationship between the variables $X$ and $Y$ given variable $Z$, while a low CMI value represents independence between genes. If the MI or CMI value is smaller than a given threshold $\theta$, the edge between the two proteins is deleted for the independence (See the detailed procedure of PCA-CMI in [20]).

We simplified the initial IRN based on PCA-CMI. We deleted the edges of the initial IRN with independent 
correlations recursively (i.e., from low to high order of independent correlation until no edge can be deleted). The threshold value $\theta$ of MI and CMI was set to 0.1 , which was statistically tested by Z-statistic [15,20,38] (Figure 2). The simplified network, which contains 50 nodes and 142 directed edges, is depicted in Figure 3.

\section{Mathematical model of the network}

To further obtain the more simplified IRN, we built nonlinear ordinary differential equations (ODEs) to model the reaction kinetics of the regulatory network. The ODEs describe the relationship between the reaction rate and the concentrations of the reactants. The change in concentration of a reactant is characterized by a function that takes the regulatory influence (activation or inhibition) of other reactants into account. The general form of nonlinear ODEs is described as follows:

$$
\frac{d x_{i}}{d t}=f_{i}\left(x_{1}, x_{2}, \ldots, x_{m}, k_{i_{-}}\right)-d_{i} x_{i}
$$

where $x_{i}$ is the concentration of species $i, f_{i}$ is a nonlinear function, $m$ is the number of species in the system, $k_{i j}$ is the kinetic parameter with $i, j \in\{1,2, \ldots, m\}$ and $d_{i}$ is the degradation rate of species $i$.

Based on the law of mass action and Hill functions, the nonlinear ODEs including 50 equations and 192 kinetic parameters were built. All equations and their explanations and the initial concentrations of proteins are listed in Additional file 3.

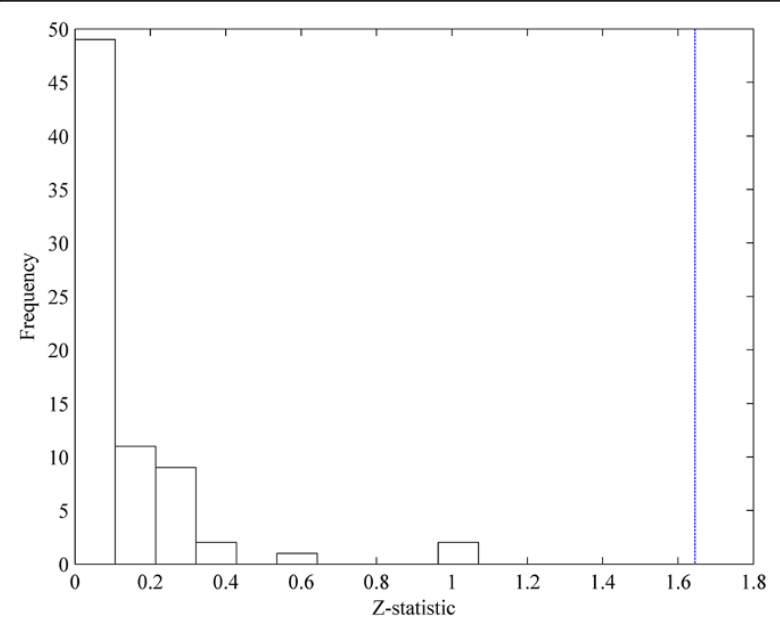

Figure 2 The significance test for the selected threshold value of the MI and CMI. The X-axis is the Z-statistic values of the deleted edges when the threshold value of $\mathrm{MI}$ and $\mathrm{CMI}$ is set to be 0.1. The $y$-axis represents the number of edges whose Z-statistic fall into the corresponding bins. The blue dashed line is the inverse cumulative distribution function of $N(0,1)$ when using significant level $a=0.1$.

\section{Estimation of the kinetic parameters in the model with the DE algorithm}

The parameters in our ODEs can be classified into two categories of regulatory parameters: parameters representing activation or inhibition relations and degradation parameters representing the degradation of individual biomolecular species.

The problem that identifies the kinetic parameters in the model can be converted into the following nonlinear optimization problem, which is the minimization of the error between the simulation values in our model and the experimental data.

$$
\min _{K} \sum_{i=1}^{N} \sum_{j=1}^{M} \omega_{i}\left(x_{i}^{\operatorname{sim}}\left(t_{j}, K\right)-x_{i}{ }^{\exp }\left(t_{j}\right)\right)^{2},
$$

where $x_{i}^{\exp }\left(t_{j}\right)$ and $x_{i}^{s i m}\left(t_{j}, K\right)$ are the experiment data and simulation value of the species $i$ at $t_{j}$ time point respectively. $\omega_{i}=1 /\left(\max _{j} x_{i} \exp \left(t_{j}\right)\right)^{2}, K$ is the parameter set consisting of all the parameters in the model, $N$ is the number of species and $M$ is the number of time points in the biological experiments.

A wide variety of global optimization techniques have been developed to address nonlinear optimization problems [39-42]. The DE algorithm, proposed by Storn and Price [42], is a very successful and powerful populationbased stochastic search technique for solving global optimization problems and has been widely applied in many scientific and engineering fields $[43,44]$. The DE algorithm is described as follows:

Step 1. Initialization: Generate random initial population $X_{G}=\left\{X_{1, G}, X_{2, G}, \ldots, X_{N, G}\right\}$, where $X_{i, G}=\left\{X_{i 1, G}, X_{i 2}\right.$, $\left.{ }_{G}, \ldots, X_{i D, G}\right\} . N$ is the population size , $\mathrm{G}$ is the generation, $X_{i, G}$ is a rate constant set and $D$ is the amount of the kinetic parameters.

Step 2. Genetic operation:

1) Mutation: $V_{i, G+1}=X_{r 1, G}+F\left(X_{r 2, G^{-}} X_{r 3, G}\right), r_{1}, r_{2}$, $r_{3} \in\{1, \ldots, N\} \backslash\{\mathrm{i}\}, F \in[0,2]$.

2) Crossover: $U_{i, G+1}=\left(U_{1 i, G+1}, \ldots, U_{D i, G+1}\right)$

$$
\begin{aligned}
U_{j i, G+1} & =\left\{\begin{array}{l}
V_{j i, G+1}, \text { if }(\operatorname{rand}(b(j)) \leq C R) \text { or } j=\operatorname{rnbr}(i) \\
X_{j i, G+1}, \text { if }(\operatorname{rand}(b(j))>C R) \text { or } j \neq \operatorname{rnbr}(i)
\end{array},\right. \\
j & =1,2, \cdots, D,
\end{aligned}
$$

where $\operatorname{rand}(b(j))$ is the $j$ th evaluation of a uniform random number in $[0,1], C R$ is the crossover constant in $[0,1]$ and $r n b r(i)$ is a random indexes in $\{1, \ldots, D\}$.

Step 3. Selection: If $f\left(U_{i, G}\right) \leq f\left(X_{i, G}\right)$, then $X_{i, G+1}=U_{i, G}$, else $X_{i, G+1}=X_{i, G}$, where $f$ is the objection function. 


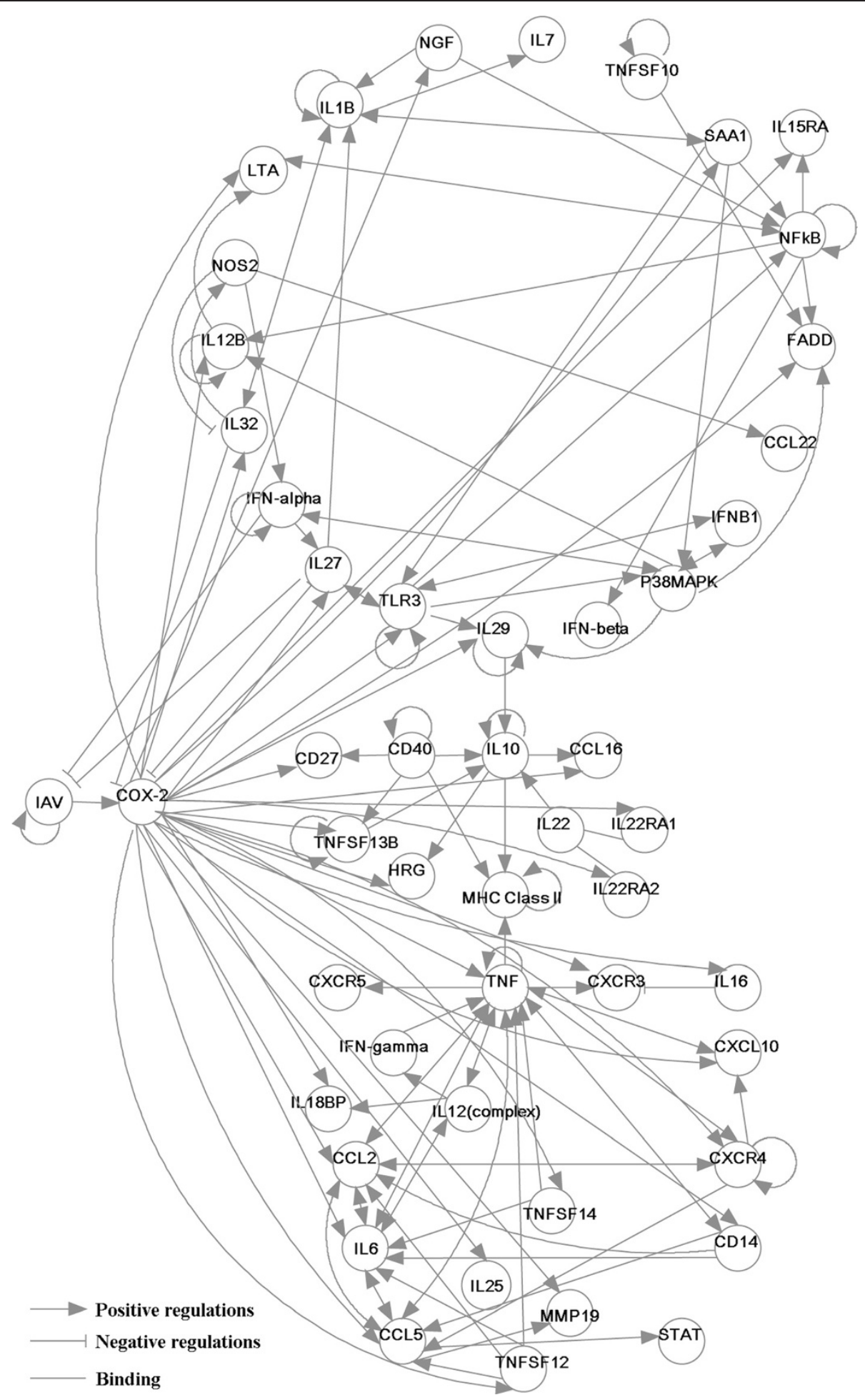

Figure 3 The simplified inflammatory regulatory network based on mutual information. The lines ended with arrows and bars denote positive and negative regulatory interactions, respectively. The lines without arrows or bars represent binding interactions. 


\section{Average relative error}

The average relative error (ARE) is defined as follows.

$$
\mathrm{ARE}=\frac{1}{n} \sum_{i=1}^{n} \frac{\left|Y^{s i m}\left(t_{i}\right)-Y^{\exp }\left(t_{i}\right)\right|}{Y^{\exp }\left(t_{i}\right)},
$$

where $Y^{\operatorname{sim}}\left(t_{i}\right)$ and $Y^{\exp }\left(t_{i}\right)$ are the simulation and experiment values of the protein at time point $t_{i}$ and $n$ is the number of samples. In this study, $n=6$.

\section{Sensitivity analysis}

Sensitivity analysis is a useful way to investigate the effects of parameters variations on changes in the model outputs. We formulate the sensitivity $s_{i}(t)$ of parameter $P$ at time $t$ as follows:

$$
\begin{aligned}
s_{i}(t) & =\frac{\partial O_{i}(t)}{O_{i}(t)} / \frac{\partial P(t)}{P(t)} \\
& \approx\left(\left|O_{i}(P+\Delta P, t)-O_{i}(P, t)\right| / O_{i}(P, t)\right) /(\Delta P / P),
\end{aligned}
$$

where $O_{i}(\mathrm{t})$ is the $i$-th model output at time $t, P$ is the parameter, $\Delta P$ is a small perturbation of $P$.

Then we define the sensitivity $S_{i}$ of the $i$-th model output with respect to parameter $P$ blow.

$$
S_{i}=\frac{1}{n} \sum_{t=1}^{n} s_{i}(t),
$$

where $n$ is the number of samples (time points).

\section{Enrichment analysis}

We conducted a functional enrichment analysis for the network based on GO Biological Processes (BP) terms and the KEGG pathway with the DAVID bioinformatics database [45]. The enrichment significance was determined by the DAVID tool. The P-values were then corrected for the false discovery rate (FDR). In this study, all the proteins other than IAV in the network are mapped with the DAVID database. For the complex, one member of the complex was mapped. The criterion for statistically significant enrichment was an FDR adjusted p-value less than 0.002 .

\section{Results}

\section{The optimized IRN based on the experimental data}

The initial and simplified IRNs (Figure 3) were constructed using IPA software and the PCA-CMI algorithm (See the Methods), respectively. To further optimize the network according to the experimental data, we first estimated all parameters in our nonlinear ODEs by the DE algorithm (See the Methods). The DE algorithm was carried out ten times, and the best parameter set was obtained, which is listed at Additional file 4: Table S2.
Second, we further deleted some nodes and edges to simplify the IRN according to the following rules. If the optimal value of the kinetic parameter $k_{i j}$ was zero, we deleted the directed edge, which indicates that biomolecular $j$ does not regulate biomolecular $i$ in the network. Furthermore, if there was no edge to connect with biomolecular $i$, we deleted the node $i$ in the network. Finally, if the node $i$ has been deleted in the network, the degradation rate $d_{i}$ was set to zero in the numerical simulation. The optimized IRN is shown in Figure 4.

Based on the optimal parameters, we performed a numerical simulation for all nodes in the network for comparison with the experimental data. The dynamical processes of 8 key proteins are plotted in Figure 5 and those of other proteins are displayed in Additional file 5 . The average relative errors (AREs) of the $98 \%$ proteins are less than 0.3 , and those of the $2 \%$ proteins are within the interval [0.3, 0.7] (Figure 6). These results indicated the fidelity of the obtained IRN. In addition, from the dynamical viewpoint, sensitivity analysis of the ODE models is very important to quantify the reliability of the parameters (regulatory strength between two genes) in the model (See the Methods). The results of the sensitivity analysis showed that the concentrations of the proteins are not sensitive to the perturbation of parameters (Figure 7), which indicating the reliability of the obtained IRN.

\section{Prediction of regulatory interactions in IRN}

Among the regulatory interactions in the optimized network, 45 interactions have been reported in the literature and are represented by red lines in Figure 4. In addition, 37 new regulatory interactions have been predicted from the network and are denoted by black lines in Figure 4. Furthermore, the statistical significance of these regulations between paired proteins was tested using the method presented in the literature $[15,20]$. The significant and non-significant regulations were denoted by thick and thin lines in Figure 4, respectively. The number of significant and non-significant regulations was summarized in Table 2. The results demonstrated that most of the predicted regulatory interactions, which are the same as the validated experimental interactions, are statistically significant.

The presence of false positive interactions is a common problem in inferring a network. One source of false positive interactions is indirect effects (i.e., in a cascade $\mathrm{A} \rightarrow$ $\mathrm{B} \rightarrow \mathrm{C}$ and $\mathrm{A} \rightarrow \mathrm{C}$, protein $\mathrm{A}$ regulates $\mathrm{C}$ and may be mediated by $\mathrm{B}$, so the direct regulatory interaction $\mathrm{A} \rightarrow \mathrm{C}$ may be a false positive interaction). Comparing the optimized IRN with the initial IRN, we have also identified 8 false positive interactions, which are shown by dashed lines in Figure 3. For example, the interactions involving the regulation of IFN- $\beta$ by TLR3 and IL6 by TNF take effects during IAV infection through other chemical molecules. In our work, we have found that TLR3 regulates 


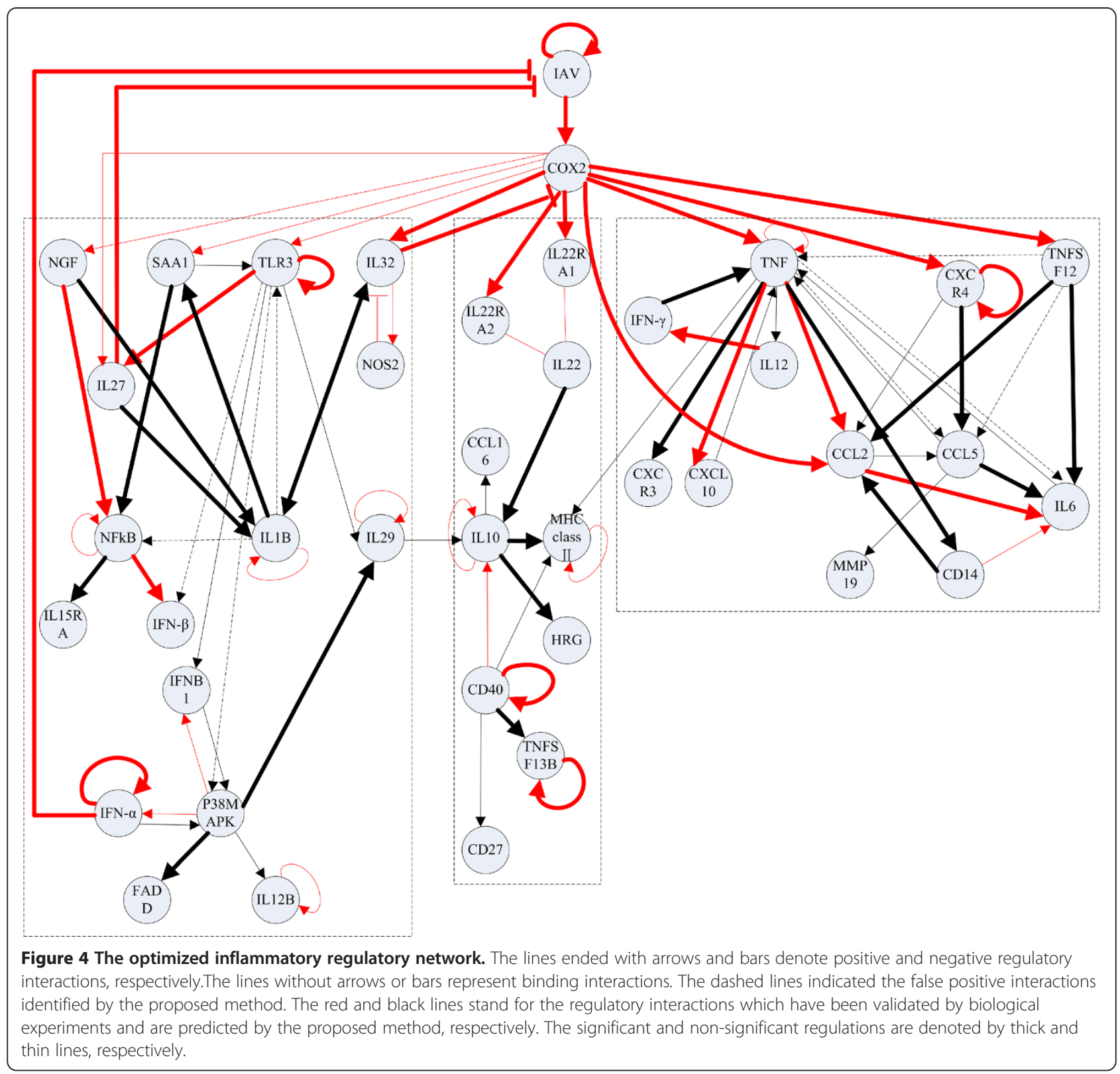

IFN- $\beta$ through NFKB signaling, which is consistent with previous findings. The TLR3-induced NFKB signaling pathway is triggered by the virus, and $N F \kappa B$ regulates expression of the proinflammatory molecule IFN- $\beta$ in the immune responses [46]. We have also found that TNF regulates IL6 mediated by the activation of CCL2 or CD14. The interactions in the optimized network are further classified, and detailed descriptions are presented in Additional file 6: Table S3.

\section{Identification of the important biological processes and pathways}

To gain further insight into the biological interpretation of the optimized IRN during IAV infection, we have performed Biological Process (BP) terms and a KEGG pathway enrichment analysis of all the species other than IAV in the optimized IRN (See the Methods). Functional enrichment analysis of the species was conducted using DAVID [45]. The annotation analysis shows enrichment in BP involved in the defense response, inflammatory response, immune response and regulation of cytokine production. The top 10 enriched BP are listed in Table 3, and all detailed lists of the significantly enriched BP terms $(\mathrm{FDR}<0.002)$ are available in Additional file 7 . In addition, network ontology analysis (NOA) which annotates biological networks [47], was used to analyze the enriched functions of the optimized IRN. The results of NOA are shown in Additional file 7. The functions of the 

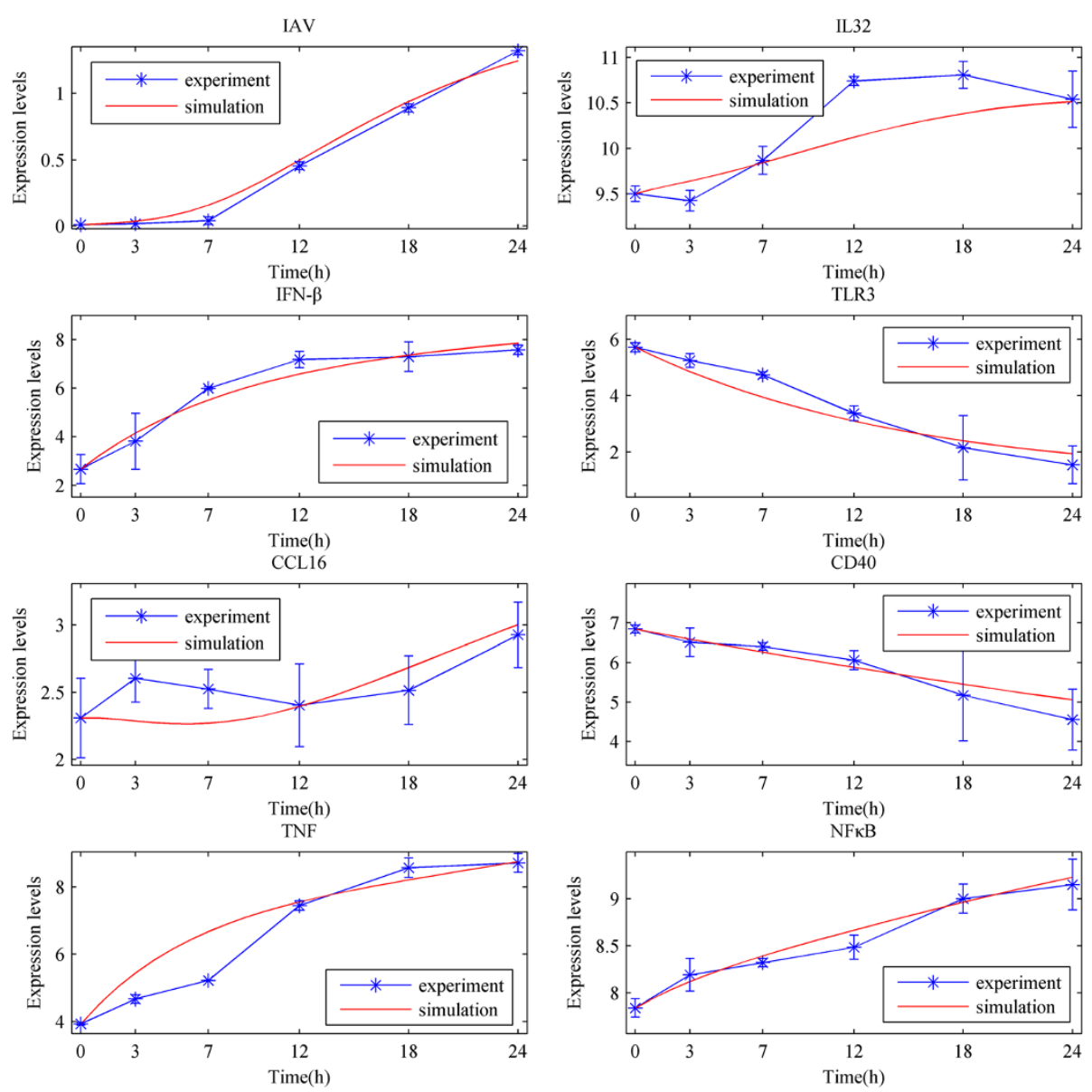

Figure 5 Comparisons between the numerical simulation results and experimental data of IAV, IL32, IFN- $\beta$, TLR3, CCL16, CD40, TNF, NFKB. The blue and red lines denote the experiment and simulation results, respectively. The stars represent experimental data at each time point. The experimental errors are also plotted as short bars at each time point.

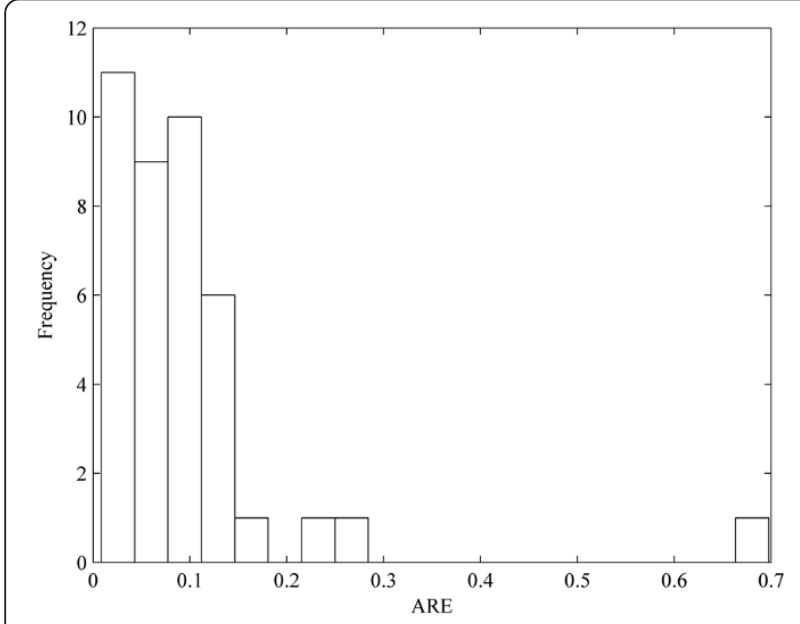

Figure 6 The distribution of the average relative errors (AREs) for the numerical simulation of the proteins in the optimized network. The $y$-axis represents the number of proteins whose AREs fall into the corresponding bins.

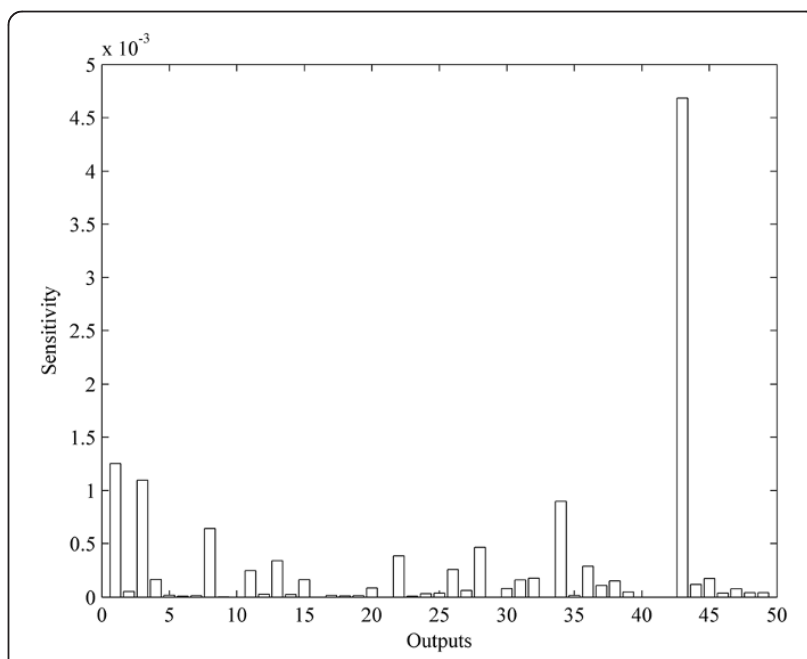

Figure 7 The sensitivity analysis for the parameters in the ODE models. The $x$-axis is the outputs (proteins) in the model and the $y$-axis is the calculated sensitivity. 
Table 2 The number of significant and non-significant regulations

\begin{tabular}{lcc}
\hline & Validated & Predicted \\
\hline Significant & 24 & 21 \\
Non-significant & 21 & 16 \\
\hline
\end{tabular}

The second and third columns are the number of regulations validated by biological experiments and predicted by our proposed method, respectively.

optimized IAV-induced IRN are enriched in the response to stimulus, immune system process, inflammatory response, response to wounding and positive regulation of cellular processes, which are similar to the results by employing DAVID. The functional annotations of the optimized IRN reveal that the reconstructed IRN functions reasonably well and they reflect the defense response, immune response, response to wounding and regulation of cytokine production are the important processes of IAV-induced inflammatory response.

The KEGG pathway enrichment analysis have identified a total of 8 pathways significantly enriched in this network $(\mathrm{FDR}<0.002)$. These pathways are shown in Table 4 . Among them, the Toll-like receptors, the RIG-I-like receptors and the NOD-like receptors have been shown to be the main pattern-recognition receptors (PRR) by which the innate immune system recognizes the influenza virus infection [48]. Moreover, the NOD-like receptors play a primary role in host defence against invading pathogens and regulating NFKB signalling, IL1 $\beta$ production, and cell death, indicating that they are crucial to the pathogenesis of a variety of inflammatory human diseases [49]. The

Table 3 Top 10 significantly enriched GO terms

\begin{tabular}{|c|c|c|}
\hline GO term (Biological Processes) & Count & FDR \\
\hline GO:0006952 defense response & 24 & $\begin{array}{l}7.01 e^{-} \\
20\end{array}$ \\
\hline GO:0006954 inflammatory response & 18 & $\begin{array}{l}9.38 \mathrm{e}- \\
16\end{array}$ \\
\hline GO:0009617 response to bacterium & 15 & $\begin{array}{l}2.53 e- \\
14\end{array}$ \\
\hline GO:0006955 immune response & 21 & $\begin{array}{c}2.65 e- \\
14\end{array}$ \\
\hline GO:0009611 response to wounding & 18 & $\begin{array}{l}3.56 \mathrm{e}^{-} \\
12\end{array}$ \\
\hline GO:0006935 chemotaxis & 12 & $\begin{array}{l}2.35 e^{-} \\
10\end{array}$ \\
\hline GO:0042330 taxis & 12 & $\begin{array}{l}2.35 e^{-} \\
10\end{array}$ \\
\hline $\begin{array}{l}\text { GO:0002684 positive regulation of immune system } \\
\text { process }\end{array}$ & 13 & $\begin{array}{l}6.24 \mathrm{e}- \\
10\end{array}$ \\
\hline $\begin{array}{l}\text { GO:0051240 positive regulation of multicellular } \\
\text { organismal process }\end{array}$ & 13 & $\begin{array}{l}8.39 \mathrm{e}- \\
10\end{array}$ \\
\hline GO:0001817 regulation of cytokine production & 12 & $\begin{array}{l}9.18 \mathrm{e}- \\
10\end{array}$ \\
\hline
\end{tabular}

The second column is the number of proteins from our protein list in the corresponding GO term.
Table 4 Significantly enriched KEGG pathways

\begin{tabular}{lccc}
\hline KEGG pathway term & Count & FDR & References \\
\hline $\begin{array}{l}\text { Hsa04060:Cytokine-cytokine receptor } \\
\text { interaction }\end{array}$ & 23 & $2.49 \mathrm{e}-19$ & {$[49,50]$} \\
$\begin{array}{l}\text { Hsa04620:Toll-like receptor signaling } \\
\text { pathway }\end{array}$ & 14 & $5.11 \mathrm{e}-12$ & {$[47,50,52]$} \\
$\begin{array}{l}\text { Hsa04672:Intestinal immune network for } \\
\text { IgA production }\end{array}$ & 8 & $1.07 \mathrm{e}-05$ & Predicted \\
$\begin{array}{l}\text { Hsa04630:Jak-STAT signaling pathway } \\
\text { Hsa04622:RIG-I-like receptor signaling }\end{array}$ & 11 & $1.30 \mathrm{e}-05$ & {$[36,49,50]$} \\
$\begin{array}{l}\text { pathway } \\
\text { Hsa04623:Cytosolic DNA-sensing }\end{array}$ & 7 & $7.51 \mathrm{e}-04$ & {$[47,53-55]$} \\
$\begin{array}{l}\text { pathway } \\
\text { Hsa04621:NOD-like receptor signaling } \\
\text { pathway }\end{array}$ & 7 & 0.001461 & Predicted \\
\begin{tabular}{l} 
Hsa05330:Allograft rejection \\
\hline
\end{tabular} & 6 & 0.001944 & Predicted \\
\hline
\end{tabular}

The second column is the number of proteins from our protein list in the corresponding $\mathrm{GO}$ term. In the last column, the corresponding references of the pathways involved in influenza A virus infection are given, and the terms "predicted" indicate that the pathways have not been reported by previous literatures.

cytokine-cytokine receptor interaction and Jak-STAT signalling pathway are also well known antiviral response pathways [50,51].

Three additional identified pathways have not been demonstrated to be associated with IAV infection. The intestinal immune network for IgA production significantly enriched (FDR=1.07e-05). Some researchers have reported that serum IgA is an inflammatory antibody that interacts with Fc $\alpha$ RI on effector immune cells and may function as a second line of defence by eliminating pathogens that have breached the mucosal surface $[56,57]$. The detection of cytosolic DNA is related to the induction of IFN- $\alpha / \beta$ and other pro-inflammatory cytokines [58-61]. Cytosolic DNA has also been shown to activate the TBK1, IRF3 and the caspase-1-dependent maturation of IL-1 $\beta$ and IL-18 [58,62]. Allograft rejection is also enriched significantly. Some authors have reported that influenza infections are associated with allograft rejection, but there is no evidence that IAV triggers the acute allograft rejection episodes [63-65]. In our results, under the stimulation of IAV, the allograft rejection pathway is significantly enriched. These three pathways lack literature support but may be promising novel pathways and need the experimental validation.

\section{Discussion}

The induction of pro-inflammatory cytokines such as COX-2, TNF, IFNs, IL27 and CXCL10 is essential for the host immune response during virus infection, but inappropriately sustained induction causes cytokinestorms, which are associated with a wide variety of infectious diseases [66,67]. Because of the complexity of the inflammatory response, it is necessary to study the 
underlying mechanisms of inflammatory response based on a network approach. In this study, we proposed a nonlinear ODE-model based computational method to construct a cell-specific IRN during IAV infection. The main contributions of this study include three aspects. First, we built the large-scaled nonlinear ODE model of the network including 50 equations and 192 kinetic parameters. Most of model-based studies for inferring networks are based on linear ODE models or discrete models [14-16], and these linear ODEs are approximated by difference equations or the steady-state assumption, which are easily solved by classical optimization algorithms or software. However, the regulatory interactions in real biological networks are often non-linear. Therefore, the non-linear ODE model can better describe the complicated regulatory networks. The comparison study for the advantage of involving nonlinear items in the model was also performed by using linear ODE model to describe the regulatory network. The AREs in the linear model exhibited significantly higher values than those in the nonlinear model (Additional file 8: Figure S1, $\mathrm{P}$-value $<0.001)$. These results indicated that the non-linear ODE model can better describe the complicated regulatory networks. Second, we combined the DE algorithm with a priori knowledge to refine the nonlinear ODEs and solve the nonlinear optimization problem derived from constructing the network. This nonlinear optimization problem is difficult to solve using classical optimization algorithms because of high nonlinearity and no explicit expression. Although DE algorithm is a published stochastic search technique, it is a repeated process from the model to optimization and then from improved model to optimization. If the model is not correct, the best optimization algorithm is also useless. Our nonlinear ODE model has been repeatedly adjusted. Finally, global errors that reflect the effectiveness of fitting the reconstructed network to experimental data are presented. In most studies based on the linear model systems, they did not provide the errors or only gave the residual errors (local errors) that cannot quantify the real error between the networks and the experimental data.

Because our proposed method integrated gene expression data with a priori knowledge of topological structure from literature and IPA software, it cannot compare with the published purely data-driven methods to evaluate the predictive results. However, these published excellent works may help us to find a more appropriate way to evaluate the approaches that combined the experimental data and a priori knowledge in the future.

An increasing number of researchers have focused on the gene expression profile of host cells infected by influenza virus [68-70]. However, most reports involve a single gene or pathway [52,53,71]. Few studies have focused on the systematic analysis of the regulation of the cell-signaling cascade by IAV. To understand the global regulatory mechanisms of the inflammatory response during IAV infection, we conducted a pathway enrichment analysis of the optimal IRN with the KEGG database. From our results, a few host cellular signaling pathways stimulated by IAV infection have been identified. Some of these signaling pathways are critical to the innate immune response of the host cell against influenza virus, such as the Toll-like receptor, the RIG-I-like receptor and the NOD-like receptor pathways $[48,54]$. The activation of the TLR signaling pathway results in the stimulation of both innate and adaptive immune responses, and TLR agonists may represent an effective and broad-spectrum antiviral strategy to combat influenza viruses [71]. Several virus-encoded components that antagonize RLR signalling interact with and inhibit the IFN- $\alpha / \beta$ activation pathway using both RNA-dependent and RNA-independent mechanisms [55,72].

Among the three novel pathways identified in our study, the functions of IgA have been studied [56,57]. Secretory immunoglobulin A (SIgA) is the major antibody isotype present in mucosal secretions and has many functional attributes, both direct and indirect, serving to prevent infective agents such as bacteria and viruses from breaching the mucosal barrier [42]. Many DNA-sensors have been reported, such as IFI16, RNA Polymerase III, DAI, AIM2, NLRP3, LRRFIP1 and DDX9/36. They play an important role in IFN- $\alpha / \beta$ and cytokine production $[54,58,73]$. For example, IFI16 can induce the inflammasome in response to Kaposi's sarcoma-associated herpesvirus infection and act as a mediator of the anti-inflammatory actions of type I IFNs [73-76]. AIM2 triggers the assembly of the inflammasome, culminating in caspase- 1 activation, IL- $1 \beta$ maturation and pyroptotic cell death [77]. LRRFIP1 has been shown to contribute to the production of IFN- $\beta$ induced by vesicular stomatitis virus (VSV) and Listeria monocytogenes in macrophages [78]. This evidence indicates that DNA sensors play an important role in virus infection. However, these results need further biological experimental verification.

It should be noted that the protein activity profiles are substituted with the corresponding gene expression levels in the computation in the study because the protein activity profile data have not been easily obtained thus far. Therefore, there may be some discrepancy when modelling the network. In addition, the network we constructed does not involve RNA components, such as target mRNAs, micro-RNAs (mi-RNAs) or other noncoding RNAs, which may also modulate signals at many steps. Recent studies have provided evidence of a potential role for long non-coding RNAs (lncRNAs) in regulating inflammatory gene expression [79,80]. Emerging evidence shows that mi-RNAs have been clearly implicated in the regulation of inflammatory responses 
[81-85]. To better understand the molecular mechanisms of the inflammatory response during IAV infection, it requires the challenging process of constructing inflammatory regulatory networks by integrating different types of data, such as gene expression data, protein activity profiles, mi-RNAs expression profiles and Chip-seq data.

\section{Conclusions}

A cell-specific IRN in IAV infection has been constructed based on the proposed method. Furthermore, 37 new regulatory interactions were predicted and 8 false positive interactions of IRN and 3 novel pathways were identified in the study. These new findings provide insight into our understanding of the mechanism of inflammatory response in IAV infection. Understanding the pivotal role of signaling pathways during IAV infection may provide new insight into therapeutic strategies for the control of virus infection and inflammatory response. Our findings also have significant implications on the development of biomarkers for infectious disease.

\section{Additional files}

Additional file 1: This file includes the initial inflammatory regulatory network by using Ingenuity Pathway Analysis (IPA) software based on the data from Gene Expression Omnibus (GEO) database under the GEO accession number GSE28166 and the website for all uploaded source codes and data.

Additional file 2: This file includes the full name of each protein in the initial IRN.

Additional file 3: This file includes the mathematical model according to the simplified network and additional Table S1 list the initial values of all components in the model.

Additional file 4: This file includes one additional Table S2 that lists the optimal parameter values obtained by DE algorithm.

Additional file 5: This file includes the comparisons between the numerical simulation results and experimental data of proteins in the optimized network.

Additional file 6: This file includes one additional Table S3 that lists the classification of the interactions in the optimized network.

Additional file 7: This file includes all significantly enriched BP terms by using DAVID and NOA.

Additional file 8: This file includes the comparison study for the advantage of involving non-linear items in the model.

\footnotetext{
Abbreviations

BP: Biological processes; CMI: Conditional mutual information; COX-2: Cyclooxygenase-2; DE: Differential evolution; FDR: False discovery rate; GEO: Gene expression omnibus; GO: Gene ontology; GRN: Gene regulatory network; IAV: Influenza A virus; IPA: Ingenuity pathway analysis;

IRN: Inflammatory regulatory network; KEGG: Kyoto encyclopedia of genes and genomes; MI: Mutual information; mi-RNAs: micro-RNAs; ODE: Ordinary differential equation; PCA: Path consistency algorithm; PRR: Pattern-recognition receptors; SlgA: Secretory immunoglobulin $A$.
}

\section{Competing interests}

The authors have declared that no competing interests exist.
Authors' contributions

XFZ designed the study, SQJ analyzed the data and performed the simulations, SQJ and XFZ wrote the paper. All authors read and approved the final manuscript.

\section{Acknowledgements}

This work was supported by the Major Research Plan of the National Natural Science Foundation of China (No. 91230118) and the National Natural Science Foundation of China (No. 61173060).

Received: 25 December 2012 Accepted: 20 September 2013

Published: 20 October 2013

\section{References}

1. Smith AM, Perelson AS: Influenza A virus infection kinetics: quantitative data and models. WIREs Syst Biol Med 2011, 3:429-445.

2. Pawelek KA, Huynh GT, Quinlivan M, Cullinane A, Rong L, Perelson AS: Modeling within-host dynamics of influenza virus infection including immune responses. PLOS Comput Biol 2012, 8: 1002588.

3. Hayden FG, Fritz R, Lobo MC, Alvord W, Strober W, Straus SE: Local and systemic cytokine responses during experimental human influenza a virus infection. relation to symptom formation and host defense. J Clin Invest 1998, 101:643-649.

4. Li W, Liu Y, Mukhtar MM, Gong R, Pan Y, Rasool ST, ChGao Y, Kang L, Hao Q, Peng GQ, Chen YN, Chen X, Wu JG, Zhu Y: Activation of interleukin-32 pro-inflammatory pathway in response to influenza a virus infection. PLoS One 2008, 3:e1985.

5. Jang H, Boltz D, McClaren J, Pani AK, Smeyne M, Korff A, Webster R, Smeyne RJ: Inflammatory effects of highly pathogenic $\mathrm{H} 5 \mathrm{~N} 1$ influenza virus infection in the CNS of mice. Neurobiol Dis 2012, 32:1545-1559.

6. Steer SA, Corbett JA: The role and regulation of COX-2 during viral infection. Viral Immunol 2003, 16:447-460.

7. Beigel JH, Farrar J, Han AM, Hayden FG, Hyer R, de Jong MD, Lochindarat S, Nguyen TK, Nguyen TH, Tran TH, Nicoll A, Touch S, Yuen KY: Avian influenza a (H5N1) infection in humans. New Engl J Med 2005, 353:1374-1385.

8. de Jong MD, Simmons CP, Thanh TT, Hien VM, Smith GJ, Chau TN, Hoang DM, Chau NV, Khanh TH, Dong VC, Qui PT, Cam BV, Ha do Q, Guan Y, Peiris JS, Chinh NT, Hien TT, Farrar J: Fatal outcome of human influenza A (H5N1) is associated with high viral load and hypercytokinemia. Nat Med 2006, 12:1203-1207

9. Lee SM, Cheung CY, Nicholls JM, Hui KP, Leung CY, Uiprasertkul M, Tipoe GL, Lau YL, Poon LL, Ip NY, Guan Y, Peiris JS: Hyperinduction of cyclooxygenase-2-mediated proinflammatory cascade: a mechanism for the pathogenesis of avian influenza H5N1 infection. J Infect Dis 2008, 198:525-535.

10. Cheung CY, Poon LL, Lau AS, Luk W, Lau YL, Shortridge KF, Gordon S, Guan Y, Peiris JS: Induction of proinflammatory cytokines in human macrophages by influenza A (H5N1) viruses: a mechanism for the unusual severity of human disease. Lancet 2002, 360:1831-1837.

11. Chan MC, Cheung CY, Chui WH, Tsao SW, Nicholls JM, Chan YO, Chan WY, Long HT, Poon LL, Guanand Y, Peiris JS: Proinflammatory cytokine responses induced by influenza a $(\mathrm{H} 5 \mathrm{~N} 1)$ viruses in primary human alveolar and bronchial epithelial cells. Resp Res 2005, 6:135.

12. Yu WC, Chan RW, Wang J, Travanty EA, Nicholls JM, Peiris JS, Mason RJ, Chan MC: Viral replication and innate host responses in primary human alveolar epithelial cells and alveolar macrophages infected with influenza H5N1 and H1N1 viruses. J Virol 2011, 85:6844-6855.

13. Fang J, Hao Q, Liu L, Li YK, Wu JG, Huo XX, Zhu Y: Epigenetic changes mediated by microRNA miR29 activate cyclooxygenase 2 and Lambda-1 interferon production during viral infection. J Virol 2012 86:1010-1020.

14. Lee WP, Tzou WS: Computational methods for discovering gene networks from expression data. Brief Bioinform 2009, 10:408-423.

15. Zhang XJ, Liu KQ, Liu ZP, Duval B, Richer JM, Zhao XM, Hao JK, Chen LN NARROMI: a noise and redundancy reduction technique improves accuracy of gene regulatory network inference. Bioinformatics 2013, 29:106-113.

16. Christley $\mathrm{S}$, Nie $\mathrm{Q}, \mathrm{Xie} \mathrm{XH}$ : Incorporating existing network information into gene network inference. PLoS One 2009, 4:e6799.

17. Küffner $R$, Petri $T$, Tavakkolkhah $P$, Windhager $L$, Zimmer R: Inferring gene regulatory networks by ANOVA. Bioinformatics 2012, 28:1376-1382. 
18. Meyer PE, Kontos K, Lafitte F, Bontempi G: Information-theoretic inference of large transcriptionalregulatory networks. Eurasip J Bioinform Syst Biol 2007, 2007:79879.

19. Huang $Q$, Wu LY, Zhang XS: An efficient network querying method based on conditional random fields. Bioinformatics 2011, 27:3173-3178.

20. Zhang XJ, Zhao XM, He K, L L, Cao YW, Liu JD, Hao JK, Liu ZP, Chen LN: Inferring gene regulatory networks from gene expression data by PC-algorithm based on conditional mutual information. Bioinformatics 2012, 28:98-104.

21. Papin JA, Hunter T, Palsson BO, Subramaniam S: Reconstruction of cellular signalling networks and analysis of their properties. Nat Rev Mol Cell Biol 2005, 6:99-111.

22. Samaga R, Saez-Rodriguez J, Alexopoulos LG, Sorger PK, Klamt S: The logic of EGFR/ErbB signaling: theoretical properties and analysis of high-throughput data. PloS Comp Biol 2009, 5:e1000438.

23. Saez-Rodriguez J, Alexopoulos LG, Epperlein J, Samaqa R, Lauffenburger DA, Klamt S, Sorger PK: Discrete logic modelling as a means to link protein signalling networks with functional analysis of mammalian signal transduction. Mol Syst Biol 2009, 5:331.

24. Morris MK, Saez-Rodriguez J, Clarke DC, Sorger PK, Lauffenburger DA: Training signaling pathway maps to biochemical data with constrained fuzzy logic: quantitative analysis of liver cell responses to inflammatorystimuli. PloS Comput Biol 2011, 7:e1001099.

25. Mitsos A, Melas IN, Siminelakis P, Chairakaki AD, Saez-Rodriguez J, Alexopoulos LG: Identifying drug effects via pathway alterations using an integer linear programming optimization formulationon phosphoproteomic data. PloS Comput Biol 2009, 5:e1000591.

26. Chen WW, Schoeberl B, Jasper PJ, Niepel M, Nielsen UB, Lauffenburger DA, Sorger PK: Input-output behavior of ErbB signaling pathways asrevealed by a mass action model trained againstdynamic data. Mol Syst Biol 2009, 5:239.

27. Chen BS, Yang SK, Lan CY, Chuang YJ: A systems biology approach to construct the gene regulatory network of systemic inflammation via microarray and databases mining. BMC Med Genomics 2008, 1:46.

28. Kirouac DC, Saez-Rodriguez J, Swantek J, Burke JM, Lauffenburger DA, Sorger PK: Creating and analyzing pathway and protein interaction compendia for modelling signal transduction networks. BMC Syst Biol 2012, 6:29.

29. Liu L, Li R, Pan Y, Chen J, Li YK, Wu JG, Zhu Y: High-throughput screen of protein expression levels induced by cyclooxygenase-2 during influenza a virus infection. Clin Chim Acta 2011, 412:1081-1085.

30. Li W, Yang F, Liu Y, Gong R, Liu L, Feng Y, Hu P, Sun W, Hao Q, Kang L, Wu JG, Zhu Y: Negative feedback regulation of IL-32 production by Inos activation in response to dsRNA or influenza virus infection. Eur $J$ Immunol 2009, 39:1019-1024.

31. Edgar R, Domrachev M, Lash AE: Gene expression omnibus: NCBI gene expression and hybridization array data repository. Nucleic Acids Res 2002, 30:207-210.

32. Li CJ, Bankhead A III, Eisfeld AJ, Hatta Y, Jeng S, Chang JH, Aicher LD, Proll S, Ellis AL, Law GL, Waters KM, Neumann G, Katze MG, McWeeney S, Kawaoka Y: Host regulatory network response to infection with highly pathogenic H5N1 Avian influenza virus. J Virol 2011, 85:10955-10967.

33. Liu L, Cao ZY, Chen J, Li R, Cao YH, Zhu CL, Wu KL, Wu JG, Liu F, Zhu Y: Influenza a virus induces interleukin-27 through cyclooxygenase-2 and protein kinase a signaling. J Biol Chem 2012, 287:11899-11910.

34. Li W, Sun W, Liu L, Yang F, Li YK, Chen YN, Fang JL, Zhang WJ, Wu JG, Zhu Y: A host proinflammatory factor against influenza viral replication is upregulated by aberrant epigenetic modifications during influenza a virus infection. J Immunol 2010, 185:5056-5065

35. Cheney KM, MCKnight A: Interferon-alpha mediates restriction of human immunodeficiency virus type- 1 replication in primary human macrophages at an early stage of replication. PLoS One 2010, 5:e13521.

36. Goodbourn S, Didcock L, Randall RE: Interferon: cell signalling, immune modulation, antiviral response and virus countermeasures. J Gen Virol 2000, 81:2341-2364.

37. Jewell NA, Cline T, Mertz SE, Smirnov SV, Flaño E, Schindler C, Grieves JL, Durbin RK, Kotenko SV, Durbin JE: Lambda interferon is the predominant interferon induced by influenza a virus infection in vivo. J Virol 2010, 84:11515-11522.

38. Kalisch $M$, Bühlmann P: Estimating high-dimensional directed acyclic graphs with the PC-algorithm. J Mach Learn Res 2007, 8:613-636.

39. Kennedy J, Eberhart R: Particle swarm optimization. Proc IEEE Int Conf Neural Network 1995, 4:1942-1948.
40. Mucherino A, Seref O: Modeling and solving real life global optimization problems with meta-heuristic methods. Adv Model Agrl Syst 2009, 25:403-419.

41. Rao RV, Savsani VJ, Vakharia DP: Teaching-learning-based-optimization a novel optimization method for continuous non-linear large scale problems. Inform Sciences 2012, 183:1-15.

42. Storn $R$, Price K: Dierential evolution-a simple and eiffient heuristic strategy for global optimization over continuous spaces. J Global Optim 1997, 11:341-359.

43. Liu J, Lampinen J: A fuzzy adaptive differential evolution algorithm. Soft Comput 2005, 9:448-462.

44. Storn R: System design by constraint adaptation and differential evolution. IEEE Trans Evol Comput 1999, 3:22-34.

45. Huang DW, Sherman BT, Lempicki RA: Systematic and integrative analysis of large gene lists using DAVID bioinformatics resources. Nat Protoc 2009, 4:44-57.

46. Jiang Z, Mak TW, Sen G, Li X: Toll-like receptor 3-mediated activation of NF-kappaB and IRF3 diverges at Toll-IL-1 receptor domain-containing adapter inducing IFN-beta. Proc Natl Acad Sci U S A 2004, 101:3533-3538.

47. Wang JG, Huang Q, Liu ZP, Wang Y, Wu LY, Chen LN, Zhang XS: NOA: a novel network ontology analysis method. Nucleic Acids Res 2011, 39(13):e87.

48. Ichinohe $\mathrm{T}$, Iwasaki $\mathrm{T}$, Hasegawa $\mathrm{H}$ : Innate sensors of influenza virus: clues to developing better intranasal vaccines. Expert Rev Vaccines 2008, 7:1435-1445

49. Chen G, Shaw MH, Kim YG, Nuñez G: NOD-like receptors: role in innate immunity and inflammatory disease. Annu Rev Pathol Mech 2009, 4:365-398.

50. Chakrabarti AK, Vipat VC, Mukherjee S, Singh R, Pawar SD, Mishra AC: Host gene expression profiling in influenza a virus-infected lung epithelial (A549) cells: a comparative analysis between highly pathogenic and modified H5N1 viruses. Virol J 2010, 7:219.

51. Boon AC, Finkelstein D, Zheng M, Liao G, Allard J, Klumpp K, Webster R, Peltz G, Webby RJ: H5N1 influenza virus pathogenesis in genetically diverse mice is mediated at the level of viral load. M Bio 2011, 2:e00171-11.

52. Talon J, Horvath CM, Polley R, Basler CF, Muster T, Palese P, García-Sastre A: Activation of interferon regulatory factor 3 is inhibited by the influenza virus NS1 protein. J Virol 2000, 74:7989-7996.

53. Pleschka S, Wolff T, Ehrhardt C, Hobom G, Planz O, Rapp UR, Ludwig S: Influenza virus propagation is impaired byinhibition of the Raf/MEK/ERK signalling cascade. Nat Cell Biol 2001, 3:301-305.

54. Chiu YH, Macmillan JB, Chen ZJ: RNA polymerase III detects cytosolic DNA and induces type i interferons through the RIG-I pathway. Cell 2009, 138:576-591.

55. Leung DW, Basler CF, Amarasinghe GK: Molecular mechanisms of viral inhibitors of RIG-I-like receptors. Trends Microbiol 2012, 20:139-146.

56. Sinkora M, Sun J, Butler JE: Antibody repertoire development in fetal and neonatal piglets.V.VDJ gene chimeras resembling geneconversion are generated at high frequency by PCR in vitro. Mol Immuno/ 2000, 37:1025-1034.

57. Snoecka V, Peters IR, Cox E: The IgA system: a comparison of structureand function in different species. Vet Res 2006, 37:455-467.

58. Thompson MR, Kaminski JJ, Kurt-Jones EA, Fitzgerald KA: Pattern recognition receptors and the rnnate immune response to viral infection. Viruses 2011, 3:920-940.

59. Keating SE, Baran M, Bowie AG: Cytosolic DNA sensors regulating type I interferon induction. Trends Immunol 2011, 32:574-581.

60. Wang ZC, Choi MK, Ban T, Yanai H, Negishi H, Lu Y, Tamura T, Takaoka A Nishikura K, Taniguchi T: Regulation of innate immune responses by DAI (DLM-1/ZBP1) and other DNA-sensing molecules. Proc Natl Acad Sci USA 2008, 105:5477-5482.

61. Takaoka A, Wang ZC, Choi MK, Yanai H, Negishi H, Ban T, Lu Y, Miyagishi M, Kodama T, Honda K, Ohba Y, Taniguchi T: DAI (DLM-1/ZBP1) is a cytosolic DNA sensor and an activator of innate immune response. Nature 2007, 448:501-505.

62. Rathinam VA, Jiang ZZ, Waggoner SN, Sharma S, Cole LE, Monks BG, Ganesan S, Latz E, Hornung V, Vogel SN, Szomolanyi-Tsuda E, Fitzgerald EA The AIM2 inflammasome is essential for host defense against cytosolic bacteria and DNA viruses. Nat Immunol 2010, 11:395-402.

63. Stucchi RS, Boin IF, Angerami RN, Sinckoc V, Sa FC, Seva-Pereira T, Escanhoela CA: Correlations between A/H1N1 influenza and acute cellular rejection in liver transplantation patients. Transp/ P 2010, 42:4184-4186.

64. Hurst FP, Lee JJ, Jindal RM, Agodoa LY, Abbott KC: Outcomes associated with influenza vaccination in the first year after kidney transplantation. Clin J AM Soc Nephro 2011, 6:1192-1197. 
65. LaRosa DF, Rahman $A H$, Turka LA: The innate immune system in allograft rejection and tolerance. J Immunol 2007, 178:7503-7509.

66. Gruta NL, Kedzierska K, Stambas J, Doherty PC: A question of self-preservation: immunopathology in influenza virus infection. Immunol Cell Biol 2007. 85:85-92.

67. Tisoncik JR, Korth MJ, Simmons CP, Farrar J, Martin TR, Katze MG: Into the eye of the cytokine storm. Microbiol Mol Biol Rev 2012, 76:16-32.

68. Geiss GK, Salvatore M, Tumpey TM, Carte VS, Wang XY, Basler CF, Taubenberger JK, Bumgarner RE, Palese P, Katze MG, García-Sastre A: Cellular transcriptional profiling in influenza a virus-infected lung epithelial cells: the role ofthe nonstructural NS1 protein in the evasionof the host innate defense and its potentialcontribution to pandemic influenza. Proc Natl Acad Sci U S A 2002, 99:10736-10741.

69. Woods CW, McClain MT, Chen M, Zaas AK, Nicholson BP, Varkey J, Veldman T, Kingsmore SF, Huang Y, Lambkin-Williams R, Gillbert AG, Hero AO 3rd, Ramsburg E, Glickman S, Lucas JE, Carin L, Ginsburg GS: A host transcriptional signature for presymptomatic detection of infection in humans exposed to influenza H1N1 or H3N2. PLoS One 2013, 8:e52198.

70. Coombs KM, Berard A, Xu WH, Krokhin O, Meng XB, Cortens JP, Kobasa D, Wilkins J, Brown EG: Quantitative proteomic analyses of influenza virus-infected cultured human lung cells. J Virol 2010, 84:10888-10906.

71. Wong JP, Christopher ME, Viswanathan S, Karpoff N, Dai X, Das D, Sun LQ, Wang M, Salazar AM: Activation of toll-like receptor signaling pathway for protection against influenza virus infection. Vaccine 2009, 27:3481-3483.

72. Ramos HJ, Gale M: RIG-I like receptors and their signaling crosstalk in the regulation of antiviral immunity. Curr opin virol 2011, 1:167-176.

73. Duan X, Ponomareva L, Veeranki S, Panchanathan R, Dickerson E, Choubey D: Differential roles for the interferon-inducible IFI16 and AIM2 innate immune sensors for cytosolic DNA in cellular senescence of human fibroblasts. Mol Cancer Res 2011, 9:589-602.

74. Kerur N, Veettil MV, Sharma-Walia N, Bottero V, Sadagopan S, Otageri P, Chandran B: IFI16 acts as a Nuclear pathogen sensor to induce the inflammasome in response to kaposi sarcoma-associated herpesvirus infection. Cell Host Microbe 2011, 9:363-375.

75. Unterholzner L, Keating SE, Baran M, Horan KA, Jensen SB, Sharma S, Sirois CM, Jin TC, Latz E, Xiao TS, Fitzgerald KA, Paludan SR, Bowie AG: IFI16 is an innate immune sensor for intracellular DNA. Nat Immunol 2010, 11:997-1004.

76. Veeranki S, Duan X, Panchanathan R, Liu H, Choubey D: IFI16 protein mediates the anti-inflammatory actions of the type-I interferons through suppression of activation of caspase-1 by inflammasomes. PLoS One 2011, 6:e27040.

77. Schroder K, Muruve DA, Tschopp J: Innate immunity: cytoplasmic DNA sensing by the AIM2 inflammasome. Curr Biol 2009, 19:262-265.

78. Yang PY, An HZ, Liu XG, Wen MY, Zheng YY, Rui YC, Cao XT: The cytosolic nucleic acid sensor LRRFIP1 mediates the production of type I interferon via a beta-catenin-dependent pathway. Nat Immunol 2010, 11:487-494.

79. Guttman M, Amit I, Garber M, French C, Lin MF, Feldser D, Huarte M, Zuk O, Carey BW, Cassady JP, Cabili MN, Jaenisch R, Mikkelsen TS, Jacks T, Hacohen N, Bernstein BE, Kellis M, Regev A, Rinn JL, Lander ES: Chromatin signature reveals over athousand highly conserved large non-coding RNAs inmammals. Nature 2009, 458:223-227.

80. Lefevre P, Witham J, Lacroix CE, Cockerill PN, Bonifer C: The LPS-induced transcriptionalupregulation of the chicken lysozyme locus involves CTCF eviction and noncoding RNA transcription. Mol Cell 2008, 32:129-139.

81. Sonkoly E, Ståhle M, Pivarcsi A: MicroRNAs and immunity: novel players in the regulation of normal immune function and inflammation. Semin Cancer Biol 2008, 18:131-140

82. O'Connell RM, Taganov KD, Boldin MP, Cheng G, Baltimore D: MicroRNA-155 is induced during the macrophage inflammatory response. Proc Natl Acad SC USA 2007, 104:1604-1609.

83. Baltimore D, Boldin MP, O'Connell RM, Rao DS, Taganov KD: MicroRNAs: new regulators ofimmune cell development and function. Nat Immunol 2008, 9:839-845.
84. Li ZP, Li F, Ni M, Li P, Bo XC, Wang SQ: Characterization the regulation of herpesvirus miRNAs from the view of human protein interaction network. BMC Syst Biol 2011, 5:93

85. Wang Y, Brahmakshatriya V, Lupiani B, Reddy SM, Soibam B, Benham AL, Gunaratne P, Liu HC, Trakooljul N, Ing N, Okimoto R, Zhou H: Integrated analysis of microRNA expression and Mrna transcriptome in lungs of avian influenza virus infected broilers. BMC Genomics 2012, 13:278.

doi:10.1186/1752-0509-7-105

Cite this article as: Jin and Zou: Construction of the influenza A virus infection-induced cell-specific inflammatory regulatory network based on mutual information and optimization. BMC Systems Biology 2013 7:105.

\section{Submit your next manuscript to BioMed Central and take full advantage of:}

- Convenient online submission

- Thorough peer review

- No space constraints or color figure charges

- Immediate publication on acceptance

- Inclusion in PubMed, CAS, Scopus and Google Scholar

- Research which is freely available for redistribution

Submit your manuscript at www.biomedcentral.com/submit
C Biomed Central 